NASA/TM-2000-210362

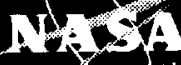

\title{
Optimizing Scale Adhesion on Single Crystal Superalloys
}

James L. Smialek

Glenn Research Center, Cleveland, Ohio

Bruce A. Pint

Oak Ridge National Laboratory, Oak Ridge, Tennessee 
Since its founding, NASA has been dedicated to the advancement of aeronautics and space science. The NASA Scientific and Technical Information (STI) Program Office plays a key part in helping NASA maintain this important role.

The NASA STI Program Office is operated by Langley Research Center, the Lead Center for NASA's scientific and technical information. The NASA STI Program Office provides access to the NASA STI Database, the largest collection of aeronautical and space science STI in the world. The Program Office is also NASA's institutional mechanism for disseminating the results of its research and development activities. These results are published by NASA in the NASA STI Report Series, which includes the following report types:

- TECHNICAL PUBLICATION. Reports of completed research or a major significant phase of research that present the results of NASA programs and include extensive data or theoretical analysis. Includes compilations of significant scientific and technical data and information deemed to be of continuing reference value. NASA's counterpart of peerreviewed formal professional papers but has less stringent limitations on manuscript length and extent of graphic presentations.

- TECHNICAL MEMORANDUM. Scientific and technical findings that are preliminary or of specialized interest, e.g., quick release reports, working papers, and bibliographies that contain minimal annotation. Does not contain extensive analysis.

- CONTRACTOR REPORT. Scientific and technical findings by NASA-sponsored contractors and grantees.
- CONFERENCE PUBLICATION. Collected papers from scientific and technical conferences, symposia, seminars, or other meetings sponsored or cosponsored by NASA.

- SPECIAL PUBLICATION. Scientific, technical, or historical information from NASA programs, projects, and missions, often concerned with subjects having substantial public interest.

- TECHNICAL TRANSLATION. Englishlanguage translations of foreign scientific and technical material pertinent to NASA's mission.

Specialized services that complement the STI Program Office's diverse offerings include creating custom thesauri, building customized data bases, organizing and publishing research results... even providing videos.

For more information about the NASA STI Program Office, see the following:

- Access the NASA STI Program Home Page at http://www.sti.nasa.gov

- E-mail your question via the Internet to help@sti.nasa.gov

- Fax your question to the NASA Access Help Desk at (301) 621-0134

- Telephone the NASA Access Help Desk at (301) 621-0390

- Write to:

NASA Access Help Desk NASA Center for AeroSpace Information 7121 Standard Drive Hanover, MD 21076 
NASA/TM-2000-210362

(2053

\section{Optimizing Scale Adhesion on Single Crystal Superalloys}

James L. Smialek

Glenn Research Center, Cleveland, Ohio

Bruce A. Pint

Oak Ridge National Laboratory, Oak Ridge, Tennessee

Prepared for the

5th International Symposium on High Temperature Corrosion and Protection of Materials sponsored by the European Federation of Corrosion Les Embiez, France, May 22-26, 2000

National Aeronautics and

Space Administration

Glenn Research Center 


\section{Acknowledgments}

The helpful discussions and supply of René N5 samples, with Y analyses by ICP, by Dr. J.C. Schaeffer and W.C. Murphy from General Electric Aircraft Engines, Evendale, Ohio are gratefully acknowleged.

Trade names or manufacturers' names are used in this report for identification only. This usage does not constitute an official endorsement, either expressed or implied, by the National Aeronautics and Space Administration.

Available from

NASA Center for Aerospace Information

7121 Standard Drive

Hanover, MD 21076

Price Code: A03
National Technical Information Service 5285 Port Royal Road Springfield, VA 22100

Price Code: A03

Available electronically at http://gltrs.grc.nasa.gov/GLTRS 


\title{
Optimizing Scale Adhesion on Single Crystal Superalloys
}

\author{
James L. Smialek \\ National Aeronautics and Space Administration \\ Glenn Research Center \\ 21000 Brookpark Road. \\ Cleveland, Ohio 44135 \\ Bruce A. Pint \\ Oak Ridge National Laboratory \\ Oak Ridge, TN 37831
}

\begin{abstract}
To improve scale adhesion, single crystal superalloys have been desulfurized to levels below 1 ppmw by hydrogen annealing. A transition to fully adherent behavior has been shown to occur at a sulfur level of about $0.2 \mathrm{ppmw}$, as demonstrated for PWA 1480, PWA 1484, and René $\mathrm{N} 5$ single crystal superalloys in $1100^{\circ}-1150^{\circ} \mathrm{C}$ cyclic oxidation tests up to $2000 \mathrm{~h}$. Small additions of yttrium (15 ppmw) also have been effective in producing adhesion for sulfur contents of about $5 \mathrm{ppmw}$. Thus the critical $\mathrm{Y} / \mathrm{S}$ ratio required for adhesion was on the order of 3-to-1 by weight (1-to-1 atomic), in agreement with values estimated from solubility products for yttrium sulfides. While hydrogen annealing greatly improved an undoped alloy, yielding $\leq 0.01 \mathrm{ppmw} \mathrm{S}$, it also produced benefits for $\mathrm{Y}$-doped alloys without measurably reducing the sulfur content.
\end{abstract}

\section{INTRODUCTION:}

The oxidation resistance of single crystal superalloys is a topic of significance because of increased performance demands and effects on thermal barrier coating lifetimes. While NiCoCrAlY overlay coatings minimize substrate composition effects, some results indicate that platinum aluminide diffusion coatings may be affected by the substrate composition. Excellent scale adhesion and cyclic oxidation resistance have been demonstrated for uncoated, yttrium-containing PWA 1487 [1], René N5 [2], and CMSX-4 [3,4]. The gettering mechanism of $Y$ is believed to stem from the thermodynamic stability of $\mathrm{Y}$-sulfides and the consequent prevention of free sulfur migration to the oxide-metal interface [5]. (An additional explanation is that $\mathrm{Y}$ ionic segregation at the oxide-metal interface inhibits the segregation of $S$ by changing the free energy of the interface [6].) However the addition of $\mathrm{Y}$ to single crystal superalloys may entail technical difficulties associated with mold reactions, narrow processing windows, and reduced yields.

In support of a primary role of sulfur on oxidation performance, hydrogen annealing has been used to remove the sulfur impurity to below $0.5 \mathrm{ppmw}$ and produce dramatic improvements in scale adhesion for PWA 1480, PWA 1484, René N5, René N6, and CMSX-4, all without Y [1,2,7-9]. The critical transition levels of sulfur were determined by hydrogen annealing PWA 1480 samples at various times, temperatures, and thickness to produce an adhesion map for $1100^{\circ} \mathrm{C}$ cyclic oxidation [10]. Critical sulfur values were seen to decrease with sample thickness, yielding about 0.2 ppmw $\mathrm{S}$ for a $1 \mathrm{~mm}$ thick sample. These values are now being approached $(0.3 \mathrm{ppmw})$ in bulk castings by melt desulfurization [10], but there is an overall cost penalty for either desulfurizing or $\mathrm{Y}$-doping. Low $\mathrm{Y}$ additions (10 ppmw) are sufficient to neutralize 2-4 ppmw S [11]. However a formal basis relating critical $Y$ levels to various $S$ levels is not well established. This study attempts to pinpoint the critical $\mathrm{Y}-\mathrm{S}$ values for René N5 by using different $\mathrm{Y}$ levels and by reducing the sulfur content by hydrogen annealing. In this way a variety of critical combinations of $\mathrm{Y}$ and $\mathrm{S}$ levels could be determined to optimize adhesion and guide manufacturers. 


\section{EXPERIMENTAL:}

Coupons of René N5 were obtained from General Electric Aircraft Engines having 10 different yttrium levels. They measured about $0.3 \times 1.3 \times 2.5 \mathrm{~cm}$ and were polished to a 600 grit finish on emery papers. The yttrium content was measured by inductively coupled plasma (ICP) emission spectroscopy. The yttrium and sulfur contents $( \pm 25 \%)$ were also measured by glow discharge mass spectroscopy (GDMS). The Y-free alloy contained $2.6 \mathrm{ppmw}$ sulfur and the 9 doped samples contained 3.6-6.5 ppmw sulfur, with no correlation with yttrium content. The yttrium levels of the doped alloys ranged from about $15-100 \mathrm{ppmw}$. Hydrogen annealing was performed on duplicate samples in a $5 \% \mathrm{H}_{2} / \mathrm{Ar}$ gas mixture at $1250^{\circ} \mathrm{C}$ for $100 \mathrm{~h}$, producing bright surfaces and slight weight losses $\left(0.05\right.$ to $\left.0.1 \mathrm{mg} / \mathrm{cm}^{2}\right)$. Annealing reduced the sulfur content of the undoped sample to below the detection limit of GDMS $(<0.01 \mathrm{ppmw})$. The sulfur content of the Y-doped samples remained at about 4.3-7.0 ppmw. The highest impurity levels (other than transition metal elements) were 425 ppmw C, 420 ppmw Si, and 70 ppmw B. Only C was reduced (to 100 ppmw) during annealing; 45 other impurity elements, $(\mathrm{P}, \mathrm{Na}, \mathrm{Ca}, \mathrm{In}, \mathrm{Pb}$, etc.), were not reduced substantially.

The coupons were cyclically oxidized at $1150^{\circ} \mathrm{C}$ in alumina tubes arranged vertically in a Kanthalwound resistance furnace, using 1 -h heating and $10 \mathrm{~min}$. cooling out to 10001 -h cycles. Weights, visual observations, $\mathrm{x}$-ray diffaction (XRD) of scale phases, and behavior in water immersion tests were recorded after cool-down at various intervals, primarily at 500 and $1000 \mathrm{~h}$. (Immersion was used to further degrade the oxide-metal interface bonding). Acoustic emission was performed on some samples during water immersion.

\section{RESULTS:}

The $1150^{\circ} \mathrm{C}$ cyclic oxidation weight change behavior is shown in Fig. 1. The as-received, undoped alloy exhibited considerable spallation throughout the test, leading to a final weight loss of more than $40 \mathrm{mg} / \mathrm{cm}^{2}$, Fig. 1a. Although some differences may be noted, all the Y-doped coupons exhibited nearly equivalent behavior. For all these 9 alloys, a small maximum in weight gain of about $0.7 \mathrm{mg} / \mathrm{cm}^{2}$ was achieved at about $300 \mathrm{~h}$. Afterwards, minor spallation produced gradual weight losses, reaching losses of $1-2 \mathrm{mg} / \mathrm{cm}^{2}$ at $1000 \mathrm{~h}$. The hydrogen annealed, undoped alloy exhibited very adherent behavior, Fig. 1b. Also, the hydrogen annealed, Y-doped alloys did not exhibit the distinct maximum in weight change as did the as-received samples. Thus weight gains, rather than losses, were achieved for this group at the end of the test.
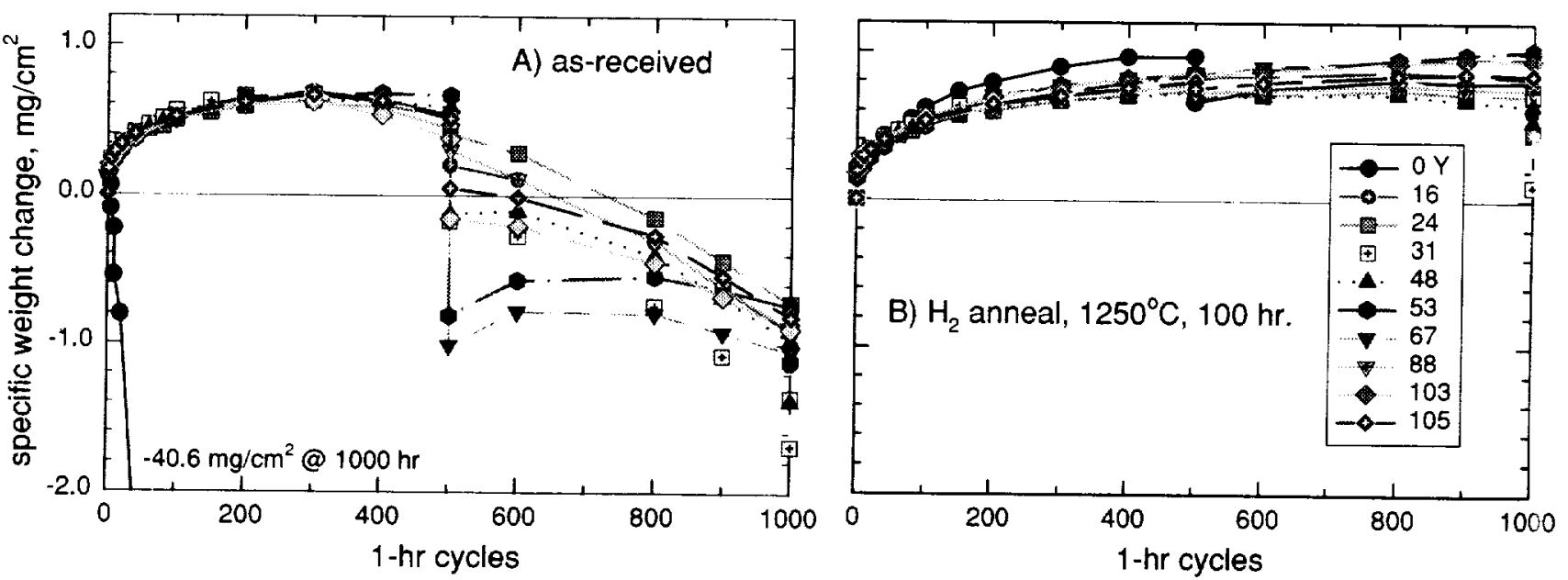

Figure 1. Cyclic oxidation behavior of Rene'N5 with various $\mathrm{Y}$ levels (ppmw) at $1150^{\circ} \mathrm{C}$, 1-h cycles: a)as-received samples; b) hydrogen annealed at $1250^{\circ} \mathrm{C}$ for $100 \mathrm{~h}$. 


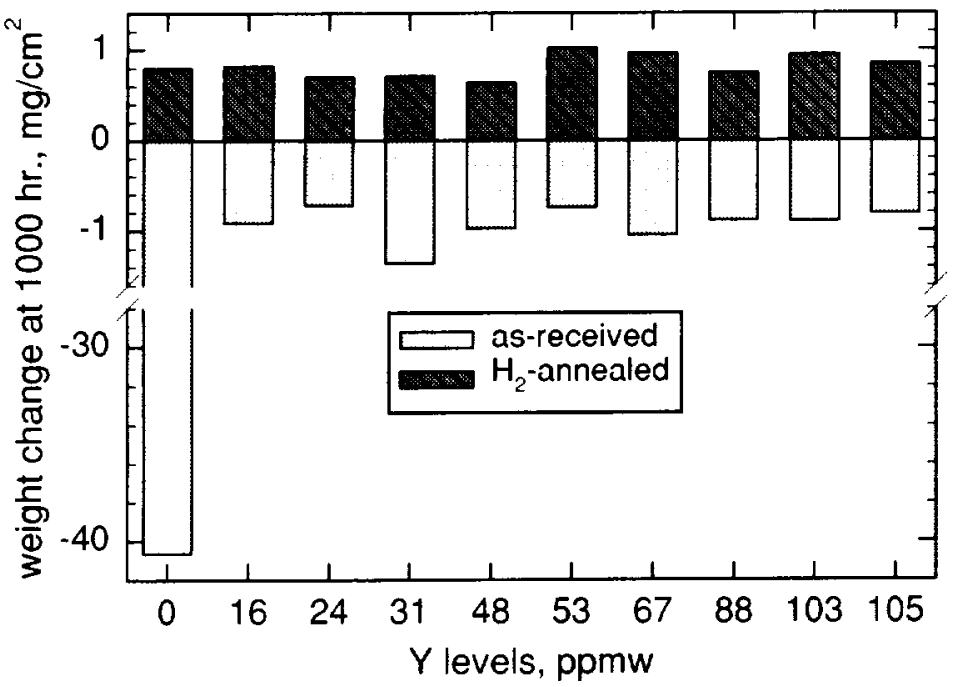

Figure 2. Summary of yttrium and hydrogen annealing effects on final weight change data (after 1000 cycles at $1150^{\circ} \mathrm{C}$ ).

The final weight changes are summarized for all the test coupons in Fig. 2. Here it can be seen at a glance that all the hydrogen annealed samples produced a small weight gain of 0.6 to $1.0 \mathrm{mg} / \mathrm{cm}^{2}$, whereas the as-received, doped samples lost 0.7 to $1.4 \mathrm{mg} / \mathrm{cm}^{2}$, showing no trend with Y level.

The scale phases formed on René $\mathrm{N} 5$ were basically $\mathrm{Al}_{2} \mathrm{O}_{3}, \mathrm{NiAl}_{2} \mathrm{O}_{4}$, and $\mathrm{NiTa}_{2} \mathrm{O}_{6}$. commonly associated with single crystal superalloy oxidation $[2,4]$. In general, the $\mathrm{NiAl}_{2} \mathrm{O}_{4}$ and $\mathrm{NiTa}_{2} \mathrm{O}_{6}$ phases are contained in an outer, transient layer that does not thicken appreciably once a protective $\mathrm{Al}_{2} \mathrm{O}_{3}$ underlayer is formed. Some peaks consistent with $\mathrm{HfO}_{2}$ were found primarily on the hydrogen annealed samples after long oxidation times.

Visual observations of spalling after cool-down were made at the weighing intervals by means of a binocular microscope at a magnification of 10x. Here small areas $\left(<1 \mathrm{~mm}^{2}\right)$ of spalling to bare metal were immediately apparent; their approximate numbers (for one side of the sample, $\sim 3.2 \mathrm{~cm}^{2}$ ) were recorded and summed over the duration of the test. The data are summarized in Fig. 3.

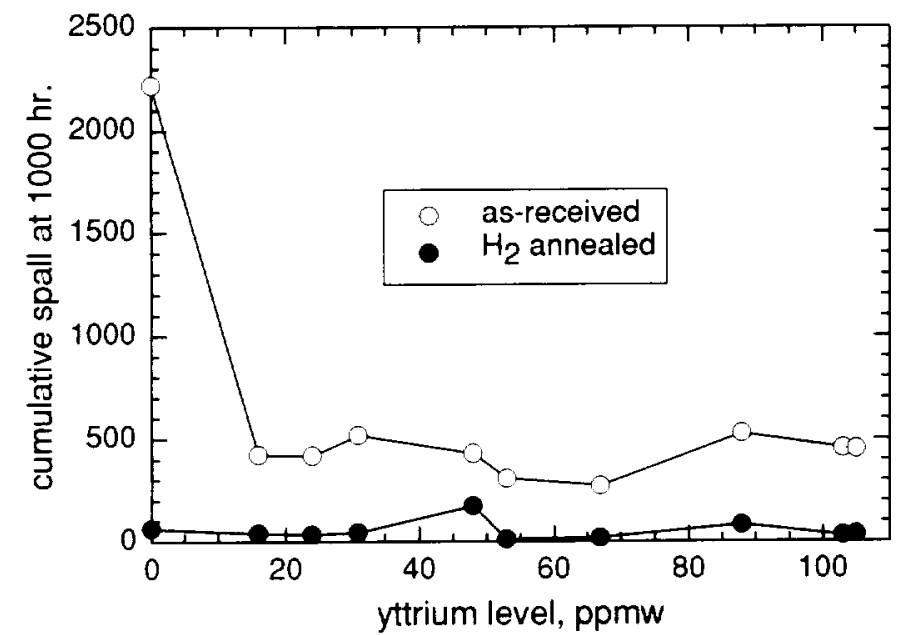

Figure 3. Cumulative number of spalled segments for René N5 cycled at $1150^{\circ} \mathrm{C}$ for $1000 \mathrm{~h}$.

The undoped, as-received sample showed by far the highest frequency of this phenomenon, numbering over 2000 such segments per side. The Y-doped, as-received samples exhibited the next highest level, gradually approaching 500 segments with time. Finally all the hydrogen annealed samples exhibited the least number, generally under 100 segments per side for the entire test. This figure confirms the lack of a clear trend with $Y$ content, substantiates the overall improvement due to hydrogen annealing, and illustrates the spalling propensity of the undoped, as-received sample. 

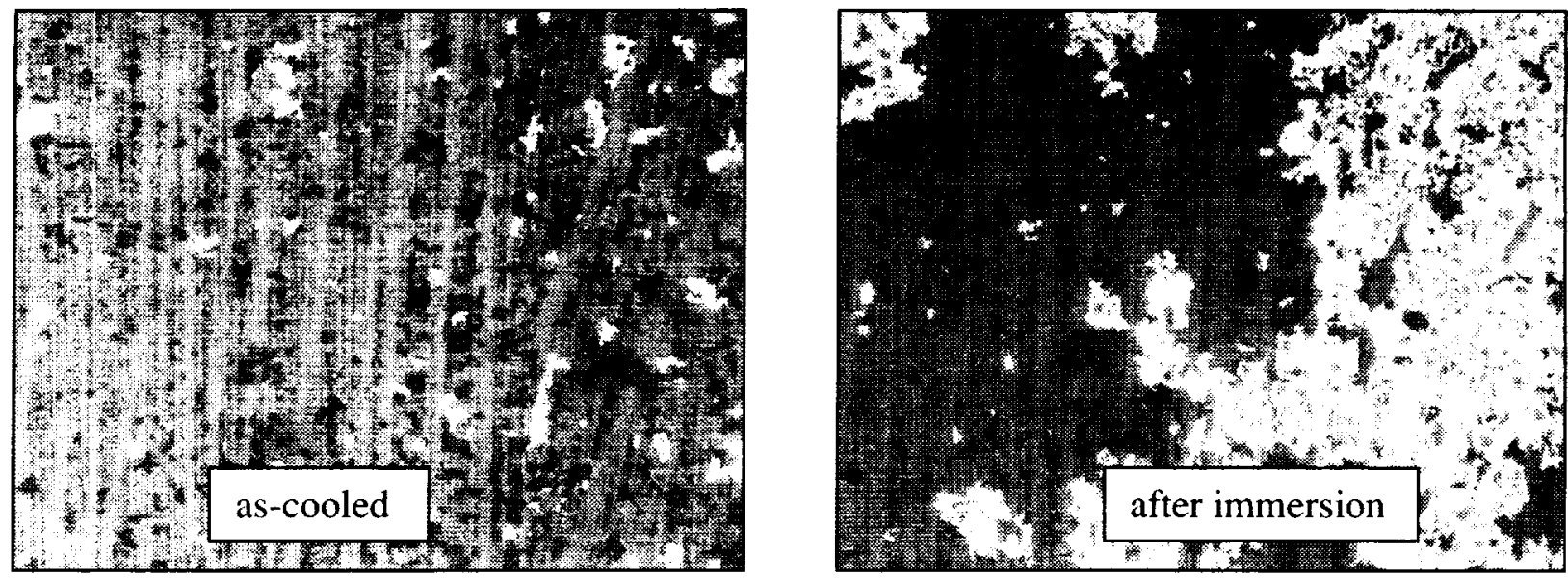

Figure 4. The effect of water immersion on scale spallation for as-received René N5 + 103 ppm Y, oxidized for $500 \mathrm{~h}$ at $1150^{\circ} \mathrm{C}$. Macrographs taken at approximately $10 \mathrm{x}$.

Also pertinent to adhesion is the effect of water immersion on bare metal spallation. In general, the as-received, undoped sample always exhibited additional spallation when immersed in room temperature water. The as-received, Y-doped samples were usually less sensitive to this phenomenon. However after 500 and 1000 hours of oxidation, the scale has thickened appreciably with commensurate increases in the interfacial stresses. Then, even Y-doped samples exhibited massive spallation to bare metal during water immersion, as shown in Fig. 4 for the 103 ppm Y alloy. This effect is summarized for all samples in terms of weight change in Fig. 5. The overall effect is that of increased resistance to water-induced spallation due to hydrogen annealing. No simple trend with Y content is apparent for the as-received samples. This effect was also followed with acoustic emission, which showed that both the number and the energy of acoustic events was much greater for as-received samples compared to those for hydrogen annealed samples.

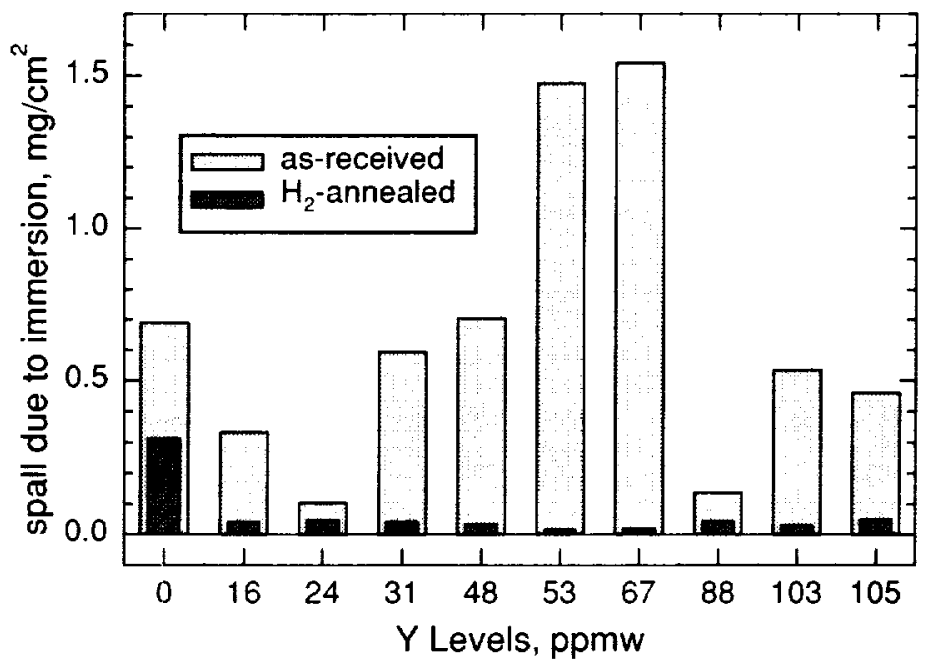

Figure 5. The effect of $\mathrm{Y}$ content and hydrogen annealing on moisture-induced spalling (after $500 \mathrm{~h}$ at $1150^{\circ} \mathrm{C}$ ).

\section{DISCUSSION:}

The obvious and primary indication of the oxidation test data was that yttrium additions were very effective in increasing scale adhesion and that the lowest level, $16 \mathrm{ppmw}$, was as effective as the highest addition, $105 \mathrm{ppmw}$. Hydrogen annealing also was very effective, as had been shown many times before, in improving scale adhesion for the undoped alloy. This resulted from removing the sulfur impurity (from $2.6 \mathrm{ppmw}$ down to $<0.01 \mathrm{ppmw}$ ). 


\subsection{Unusual behavior:}

However, there are a number of unexpected and less understood results. Unfortunately, from a test variable standpoint, the lowest $\mathrm{Y}$ level appeared to be fully effective in gettering sulfur. Low Y levels not only produced excellent oxidation behavior, but also prevented further desulfurization during hydrogen annealing. This means that there was only one alloy that showed any significant variation in oxidation and desulfurization by hydrogen annealing - the undoped alloy. No further information can be obtained regarding the exact amount of yttrium required to deactivate the intrinsic sulfur level (3-7 ppmw) found in these alloys. Thus a series of critical Y-S combinations, producing a Y-S adhesion map, was not obtained.

The other unexpected result is that, although hydrogen annealing did not reduce the sulfur content of the Y-doped alloys, it nevertheless improved scale adhesion and oxidation behavior. This was seen from simple weight change results, Figs. 1 and 2, from the observed number of spall segments, Fig. 3, and from the effects of annealing on immersion-induced spallation, Fig. 5. A simple explanation is not obvious, but since the annealed samples were not re-polished, there is a slight possibility that the very near surface region may be sulfur-poor with respect to the bulk coupon. Simple annealing effects, i.e., without desulfurization, are not likely, since single crystal superalloys are normally homogenized/solution annealed above $1250^{\circ} \mathrm{C}$.

Some insight, however, can be gained regarding the role of Hf, present in this alloy and PWA 1484 at about the 0.1-0.2 wt.\% level ( $500 \mathrm{ppma})$. In simple $\mathrm{NiAl}$ [12] and $\mathrm{MCrAl}$ alloys, the effectiveness of Hf doping is remarkable and well known. However, it is clear that Y doping is superior for complex MCrAl superalloys such as René N5 and that substantial desulfurization by hydrogen annealing is still possible in the presence of $\mathrm{Hf}$. One possible reason for this difference is that $\mathrm{Hf}$ is tied up as a carbide [1,13]. Hydrogen annealing removes carbon and releases free Hf, which may then become more effective as a sulfur getter and/or interfacial segregant. Improved behavior is thus noted for hydrogen annealed superalloys with Hf (PWA 1484) compared to those without (PWA 1480) [13]. However, recently it has been shown that hydrogen annealing also dramatically improved the spallation resistance of $\mathrm{Ni}-7 \mathrm{Cr}-6 \mathrm{Al}+\mathrm{Hf}$ model alloys, where no $\mathrm{C}(<100$ ppmw) has been added intentionally [14].

\subsection{Critical Y, S levels:}

Given the present situation, it is still instructive to discuss the implications of the effects of various Y-S levels on oxidation behavior. The simplest approach would be to address oxidation behavior in terms of an Y/S ratio, assuming sulfur gettering is due to the formation of stable yttrium sulfides or oxysulfides. Accordingly, the final weight change occurring after 1000 1-h cycles was presented as a function of the Y/S ratio (using ppm atomic) in Fig. 6.

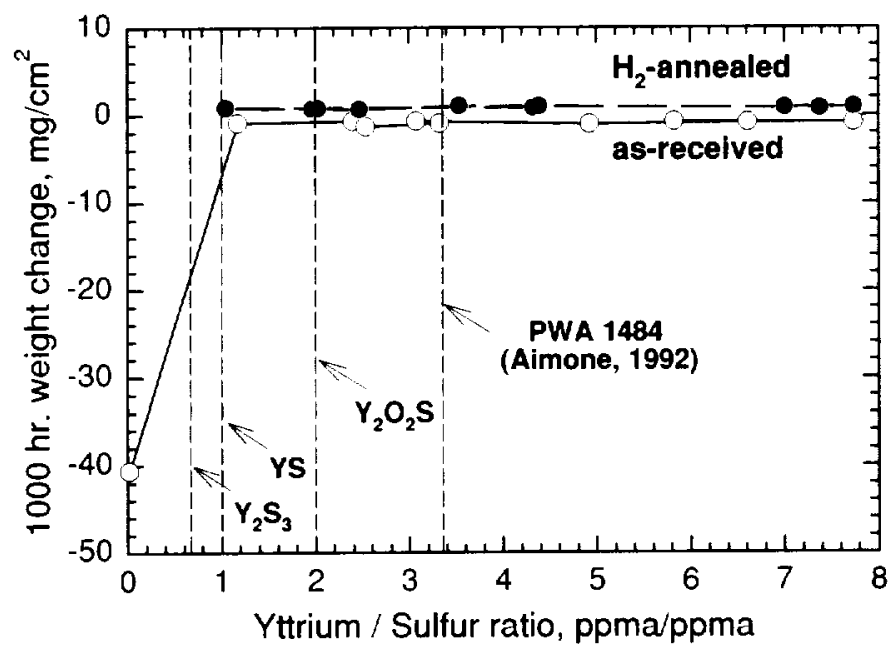

Figure 6. The effect of $\mathrm{Y} / \mathrm{S}$ atom ratio on the final weight change after $1150^{\circ} \mathrm{C}$ cyclic oxidation of René N5. 
It can be seen that the oxidation behavior was similar for all the Y-doped alloys; these had $\mathrm{Y} / \mathrm{S}$ atomic ratios greater than or equal to about 1 . These alloys, then, provide only an upper limit to a critical Y/S ratio. The only non-adherent alloy was the one not intentionally $Y$-doped, in the asreceived condition. It contained a trace level of $Y$ of about 0.1 ppma $(0.14$ ppmw) and 4.9 ppma $S$ (2.6 ppmw), yielding a very low $\mathrm{Y} / \mathrm{S}$ ratio of 0.02 . Consequently, we can only infer that the critical $\mathrm{Y} / \mathrm{S}$ ratio lies somewhere between 0.02 and 1 , or below the value expected for an YS compound. The values for the stable compounds $\mathrm{Y}_{2} \mathrm{~S}_{3}(0.667)$ and $\mathrm{Y}_{2} \mathrm{O}_{2} \mathrm{~S}(2.0)$ are also seen to be relatively close in comparison to the transition region. A similar experimental study of Y-doped PWA 1484 produced a critical $\mathrm{Y} / \mathrm{S}$ ratio between about 0.4 and 3.3 [11], overlapping much of the critical region bracketed by the present study.

The above rationale (yttrium sulfide stoichiometries) is based on simple chemistry and is useful as a straightforward engineering figure of merit. However it would be more precise to describe the segregation potential of sulfur as a function of yttrium content, in the sense of Luthra and Briant [15]. Here the degree of sulfur interfacial segregation was thermodynamically defined on the basis of the enthalpy of segregation, the free energy of sulfide formation, and the activities of $\mathrm{Y}$ and $\mathrm{S}$ in solid solution. Unfortunately, the lack of thermodynamic quantities prevents a complete treatment.

Another approach by Meier and Pettit estimated values for the solubility product of yttrium sulfide and then calculated corresponding residual concentrations of $Y$ and $S$ that remain mobile in solution [13]. Thus for the reaction with $Y S$ at unit activity, where $K_{S P}$ is the solubility product and $C_{Y, R}$, $\mathrm{C}_{S, \mathrm{R}}$ are the concentrations of residual $\mathrm{Y}$ and $\mathrm{S}($ at.\%) that remain in solution:

$$
\begin{aligned}
& Y S=Y+S \\
& K_{S P}=\left[C_{Y, R}\right]\left[C_{S, R}\right] \\
& C_{Y, R}=C_{Y}{ }^{o}-C_{Y} C_{S} \\
& C_{S, R}=C_{S}{ }^{o}-C_{S}{ }^{Y S} \\
& C_{Y}{ }^{Y S} \approx C_{S}{ }^{Y S}
\end{aligned}
$$

where $\mathrm{C}_{\mathrm{Y}}{ }^{\circ}$ and $\mathrm{C}_{\mathrm{S}}{ }^{\circ}$ are the total concentrations and $\mathrm{C}_{\mathrm{Y}}{ }^{\mathrm{YS}}$ and $\mathrm{C}_{\mathrm{S}}{ }^{\mathrm{YS}}$ are the levels tied up in the sulfide. A solubility product $\mathrm{K}_{\mathrm{SP}}=($ at. $\% \mathrm{Y})($ at. $\% \mathrm{~S})=7 \times 10^{-10}$ was estimated $[1,13]$. They then calculated the critical amount of Y required to "tie up" a given amount of sulfur impurity.

This same approach is now followed for various input values of $C_{S, R}^{*}$ intended to serve as the critical sulfur levels for adhesion. From mapping studies [10], it was found that the critical sulfur content (without $Y$ ) appeared to be on the order of 0.1-0.4 ppma for PWA 1480. Accordingly, a number of proximate values were input and the corresponding $\mathrm{C}_{Y}{ }^{\circ}$ required for adhesion (producing these low $C_{\text {S.R }}^{*}$ ) were calculated for various $C_{S}{ }^{0}$. The results shown in Fig. 7 present a family of curves which converge above 10 ppma. They indicate that the required $\mathrm{Y}$ level is essentially equivalent to the sulfur content (i.e., YS stoichiometry) above 10 ppma. Below 1 ppma sulfur, the required yttrium level exceeds the sulfur level, but is never higher than about 2 ppma yttrium. Note also that the total critical sulfur content, $\mathrm{C}_{S}{ }^{\circ}$, can never logically go below the corresponding residual amount, $C_{S, R}^{*}$, with the result that the curves self-truncate at this value. This left region of the plot corresponds then to ultra-low sulfur alloys, where $\mathrm{Y}$ is not required for adhesion.

The present data for various René N5 compositions are shown as large circles. All the Y-doped samples, as-received (open) or hydrogen annealed (solid), fall on or above all the curves delineated by the solubility product calculations. Since these samples all exhibited adherent behavior, this approach is in agreement with the experimental results. However, since the sulfur values were 
always at about 10 ppma, where the family of curves converges, no distinction can be made regarding the various critical values $(0.05-0.4$ ppma $S)$ proposed for $C^{*}{ }_{S . R}$.

Non-adherent behavior is of course observed for the as-received, undoped sample, whose Y level is far below that of the prescribed adhesion boundary. Finally, the ultra-low S, hydrogen annealed, undoped alloy was very adherent as predicted because its sulfur level was well below all the critical $C_{\text {S.R }}^{*}$ values, irrespective of $Y$ content.

\subsection{Moisture effects:}

This study showed the often dramatic effect of water immersion on interfacial spalling. It was most prominent on the Y-doped, as-received samples, but only after a considerable scale had been built up. The hydrogen annealed samples were generally quite resistant to this phenomenon. Water immersion was adopted as a moisture sensitivity test during some of the initial low sulfur demonstrations of adhesion without dopants [16]. It was generally observed that at intermediate sulfur levels, scale retention on cool-down could be achieved initially, but spalling continued over time or rapid extensive spalling occurred upon exposure to moisture for PWA 1480, Rene'142, and René N5 superalloys [2,7].

Subsequent studies identified that dry air exposures could control spallation at high sulfur levels for one thermal exposure of René N6 (without Y) [8]. Also cycling of PWA 1480, PWA 1484, and CMSX 4 (without $\mathrm{Y}$ ) in dry air exhibited much improved performance compared to humid air [17]. Here the effect of moisture was discussed as a stress corrosion mechanism and breaking oxidemetal Al-O-Al bridging bonds, already weakened by the presence of interfacial sulfur. It was noted that sulfur-free interfaces are intrinsically tough enough to resist moisture effects, even when direct access to the oxide-metal interface is allowed. This picture is confirmed in the present study. The assumed detrimental presence of interfacial sulfur further suggests that a reaction with water may form $\mathrm{H}_{2} \mathrm{SO}_{4}$ with an adverse effect on the interfacial chemistry. It is interesting to point out that some kind of stabilization may occur, as samples left open to the room environment for weeks are observed to become more resistant to immersion-induced spallation. Furthermore, the extremely rapid spallation events observed here do not readily fit the conventional model of slow crack growth operative in moisture-driven, stress-corrosion cracking of bulk ceramics.

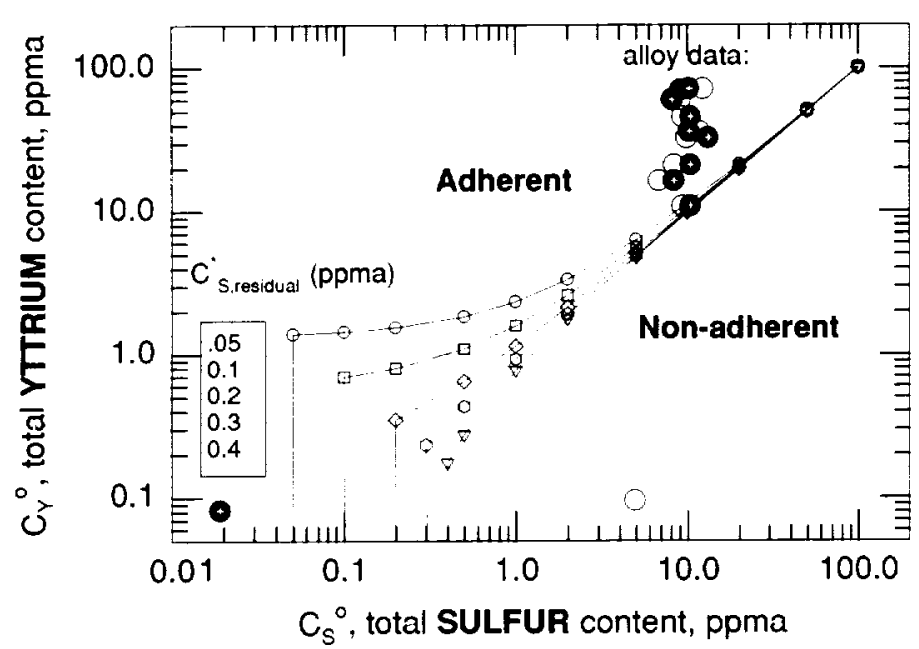

Figure 7. Critical yttrium and sulfur contents estimated according to $\mathrm{K}_{\mathrm{SP}}$ for various $C_{S . R}^{*}$ adhesion criteria; comparison to actual René N5 data. 


\section{CONCLUSIONS:}

The $1150^{\circ} \mathrm{C}$ cyclic oxidation behavior of a single crystal superalloy, René N5, is excellent when doped with $\mathrm{Y}$ at about $15 \mathrm{ppmw}$ (10 ppma) for a sulfur level of about $5 \mathrm{ppmw}$ (10 ppma), yielding a critical $\mathrm{Y} / \mathrm{S}$ ratio of about $3: 1$ by weight $(1: 1$ atomic). Thus the amount of $\mathrm{Y}$ required to promote good adhesion on these superalloys was very low. Higher $Y$ levels did not measurably improve performance. The amount of $Y$ sufficient for adhesion was also sufficient to prevent desulfurization by hydrogen annealing, consistent with the viewpoint that $Y$-doping prevents spalling by preventing sulfur segregation. The critical $\mathrm{Y} / \mathrm{S}$ value found for adhesion was consistent with that estimated from a solubility product approach, equivalent to that expected from YS stoichiometry. Hydrogen annealing produced dramatic improvements in scale adhesion for the undoped alloy because it reduced the sulfur content to $\leq 0.01 \mathrm{ppmw}$. However, hydrogen annealing also improved the spallation resistance of the Y-doped alloys, without measurably reducing the sulfur content, in both oxidation and water immersion tests. These second order improvements in adhesion were achieved for all $\mathrm{Y}$ levels and suggest a synergism between desulfurization, decarburization and $\mathrm{Hf}$ doping.

\section{REFERENCES:}

1. SARIOGLU C., STINNER C., BLACHERE J.R., BIRKS N., PETTIT F.S., MEIER G.H., SMIALEK J.L., in Superalloys '96, R.D. Kissinger, et al., Eds., (The Minerals, Mining, and Materials Society, Warrendale, PA, 1996) pp. 71-80.

2. SMIALEK J.L., JAYNE D.T., SCHAEFFER J.C., MURPHY W.C., Thin Solid Films 253 (1994) 285.

3. BROOMFIELD R. W., et al., IGTI Turbo Expo 97 (ASME), 97-GT-117 (1997).

4. SMIALEK J. L, BARRETT C. A., SCHAEFFER J. C., "Design for Oxidation," in Design for Properties, ASM Handbook, 20 (ASM, Materials Park, OH, 1997), pp. 589-602.

5. SMEGGIL J.G.,. FUNKENBUSCH A.W.,.BORNSTEIN N.S., Metall. Trans. A 17 (1986) 923

6. PINT B. A. Oxid. Met. 45 (1996) 1.

7. SMIALEK J.L., TUBBS B.K., Metall. and Mat. Trans. 26A (1995) 427.

8. SMITH M.A, FRAZIER W.E., PREGGER B.A., Mat. Sci. and Engineer. A203 (1995) 388.

9. KIRCHER T. A., KHAN A., PREGGER B., paper presented at Aeromat 91, Long Beach, CA, (ASM, 1991).

10. SMIALEK J.L., in High Temperature Corrosion and Materials Chemistry, P.Y. Hou, M.J. McNallan, R. Oltra, E.J. Opila, and D.A. Shores, Eds., 98-9, (The Electrochemical Society, Pennington, NJ, 1998) pp. 211-221.

11. AIMONE P.R, McCORMICK R.L., in Superalloys '92, S.D. Antolovich et al., eds., (The Mining, Minerals, and Materials Society, Warrendale PA, 1992) 817.

12. PINT B. A., et al. Mater. Sci. and Eng. A245 (1998) 201.

13. MEIER G.H., PETTIT F.S., SMIALEK J.L., Werstoffe und Korrosion 46 (1995) 232.

14. HAYNES J.A., et al., ORNL, private communication, (May, 2000).

15. LUTHRA K.L., BRIANT C.L., Metall. Trans. 19A (1988) 2091.

16. SMIALEK J.L, in N. L. Peterson Mem. Symp. Proc. on Oxidation and Associated Mass Transport, M.A Dayananda, M.J. Rothman, and W.E. King, Eds., (TMS-AIME, Warrendale, PA, 1986) pp. 297-313.

17. JANAKIRAMAN R. J., MEIER G. H., PETTIT F. S., in Cyclic Oxidation of High Temperature Materials, M. Schütze, W. J. Quadakkers, Eds., (European Federation of Corrosion, 27, IOM, London, 1999) pp. 38-62. 


\section{REPORT DOCUMENTATION PAGE}

Public reporting burden for this collection of information is estimated to average 1 hour per response, including the time for reviewing instructions, searching existing data soufces, gathering and maintaining the data needed, and completing and reviewing the collection of information. Send comments regarding this burden estimate or any other aspect of this collection of information, including suggestions for reducing this burden, to Washington Headquarters Services, Directorate for Intormation Operations and Reports, 1215 Jefferson Davis Highway, Suite 1204, Artington, VA 22202-4302, and to the Otfice of Management and Budget, Paperwork Peduction Project (0704-0188), Washington, DC 20503.

\begin{tabular}{|l|l|l|l}
\hline 1. AGENCY USE ONLY (Leave blank) & $\begin{array}{r}\text { 2. REPORT DATE } \\
\text { August } 2000\end{array}$ & $\begin{array}{r}\text { 3. REPORT TYPE AND DATES COVERED } \\
\text { Technical Memorandum }\end{array}$ \\
\hline 4. TITLE AND SUBTITLE
\end{tabular}

Optimizing Scale Adhesion on Single Crystal Superalloys

6. AUTHOR(S)

WU-523-31-13-00

James L. Smialek and Bruce A. Pint

7. PERFORMING ORGANIZATION NAME(S) AND ADDRESS(ES)

National Aeronautics and Space Administration

John H. Glenn Research Center at Lewis Field

Cleveland, Ohio 44135-3191

5. FUNDING NUMBERS

. SPONSORING/MONITORING AGENCY NAME(S) AND ADDRESS(ES)

10. SPONSORING/MONITORING AGENCY REPORT NUMBER

National Aeronautics and Space Administration

Washington, DC 20546-0001

NASA TM-2000-210362

11. SUPPLEMENTARY NOTES

Prepared for the 5th International Symposium on High Temperature Corrosion and Protection of Materials sponsored by the European Federation of Corrosion, Les Embiez, France, May 22-26, 2000. James L. Smialek, NASA Glenn Research Center; and Bruce A. Pint, Oak Ridge National Laboratory, Oak Ridge, Tennessee 37831. Responsible person, James L. Smialek, organization code 5160, (216) 433-5500.

12a. DISTRIBUTION/AVAILABILITY STATEMENT

12b. DISTRIBUTION CODE

Unclassified - Unlimited

Subject Category: 26

Distribution: Nonstandard

This publication is available from the NASA Center for AeroSpace Information. (301) 621-0390.

13. ABSTRACT (Maximum 200 words)

To improve scale adhesion, single crystal superalloys have been desulfurized to levels below 1 ppmw by hydrogen annealing. A transition to fully adherent behavior has been shown to occur at a sulfur level of about $0.2 \mathrm{ppmw}$, as demonstrated for PWA 1480, PWA 1484, and René N5 single crystal superalloys in $1100-1150^{\circ} \mathrm{C}$ cyclic oxidation tests up to $2000 \mathrm{~h}$. Small additions of yttrium ( $15 \mathrm{ppmw}$ ) also have been effective in producing adhesion for sulfur contents of about $5 \mathrm{ppmw}$. Thus the critical Y/S ratio required for adhesion was on the order of 3-to-1 by weight (1-to-1 atomic), in agreement with values estimated from solubility products for yttrium sulfides. While hydrogen annealing greatly improved an undoped alloy, yielding $\leq 0.01 \mathrm{ppmw} \mathrm{S}$, it also produced benefits for Y-doped alloys without measurably reducing the sulfur content.

14. SUBJECT TERMS

$\mathrm{Al}_{2} \mathrm{O}_{3}$ scales; Adhesion; Superalloys; Cyclic oxidation; Sulfur; Reactive element

16. PRICE CODE

$\mathrm{AO} 3$

17. SECURITY CLASSIFICATION OF REPORT

Unclassified

TITY CLASSIFICATION OF THIS PAGE

Unclassified

9. SECURITY CLASSIFICATION OF ABSTRACT

Unclassified 